\title{
Relationship between E-cadherin, matrix metalloproteinase-7 gene expression and clinicopathological features in gastric carcinoma
}

\author{
KYUNG HEE LEE ${ }^{1}$, SANG JOON SHIN ${ }^{1}$, KYEONG OK KIM ${ }^{1}$, MIN KYOUNG KIM ${ }^{1}$, \\ MYUNG SOO HYUN ${ }^{1}$, TAE NYEUN KIM ${ }^{2}$, BYUNG IK JANG ${ }^{2}$, SANG WOON KIM ${ }^{3}$, \\ SUN KYO SONG ${ }^{3}$, HEE SUN KIM ${ }^{4}$, SUNG HWA BAE ${ }^{5}$ and HUN MO RYOO

\begin{abstract}
Divisions of ${ }^{1}$ Hemato-Oncology and ${ }^{2}$ Gastroenterology, Department of Medicine; Departments of ${ }^{3}$ Surgery and ${ }^{4}$ Microbiology, College of Medicine, Yeungnam University; ${ }^{5}$ Division of Hemato-Oncology, Department of Medicine, Catholic University Hospital, Daegu, Korea
\end{abstract}

Received March 14, 2006; Accepted June 5, 2006

\begin{abstract}
We investigated whether the abnormal expression of E-cadherin (ECD), in conjunction with the overexpression of matrix metalloproteinase-7 (MMP-7), is correlated with clinicopathological parameters such as metastasis and the prognosis for human gastric carcinoma. Using RT-PCR, we examined the expression of ECD and MMP-7 mRNA in 42 gastric carcinoma tissues and in the surrounding non-neoplastic mucosa. The macroscopic and histopathological tumor findings and the survival rates were obtained from the patient records. The level of ECD mRNA expression was lower in most of the neoplasms as compared to the corresponding nonneoplastic tissues (50 vs. 80.9\%, respectively). The abnormal expression of ECD mRNA was significantly correlated to the microscopic classification and lymph node metastases $(\mathrm{p}<0.05)$, and its stage $(\mathrm{p}<0.05)$. The level of MMP-7 mRNA expression was higher in most neoplasms compared to the corresponding non-neoplastic tissues (66.6 vs. 50\%, respectively). The overexpression of MMP-7 mRNA was significantly correlated with the microscopic classification, lymph node metastases $(\mathrm{p}<0.05)$, and its stage $(\mathrm{p}<0.01)$. However, a correlation between the abnormal expression of ECD and the overexpression of MMP-7 was not obtained. The survival rate of the patients with an ECD mRNA expression was longer than that of the patients without this expression, but this finding was not statistically significant $(\mathrm{p}=0.2162$ ). The survival rates of patients with MMP-7 mRNA expression was significantly shorter than that of the patients without MMP-7 mRNA
\end{abstract}

Correspondence to: Dr Hee Sun Kim, Department of Microbiology, College of Medicine, Yeungnam University, 317-1 Daemyung-Dong, Daegu 705-717, Korea

E-mail: heesun@med.yu.ac.kr

Key words: stomach neoplasms, E-cadherin, MMP-7 expression ( $\mathrm{p}=0.0025)$. Overexpression of MMP-7 may be considered as a useful marker for determining metastasis and the prognosis of human gastric carcinoma rather than the abnormal expression of E-cadherin.

\section{Introduction}

For the process of metastasis to occur, tumor cells must complete a multistep progression through a series of sequential and selective events (1). These events include the changes in cellular adhesion, the production of proteolytic enzymes that degrade the stroma, and the secretion of various cytokines that attract and activate stromal cells and endothelial cells during tumor invasion and angiogenesis (2). E-cadherin (ECD) is one of the most important molecules for cell-cell adhesion in epithelial tissues. Besides its role in normal cells, it can play a major role in malignant cell transformation and dysfunction in cell-cell adhesion via the suppression of the E-cadherin expression. In addition, the loss of E-cadherin may increase the pool of free $B$-catenin from the adherens junctions. Increased free $\beta$-catenin activates the transcriptional targets of the Wnt (wingless) singnalling pathway, which include c-myc, cyclin D1, c-jun, Tcf-1, PPARd and MMP-7 (3).

Matrix metallopreinases are zinc-dependent endopeptidases that are collectively capable of degrading all the constituents of the extracellular matrix (ECM) (4). Over 20 enzymes of the MMP family have recently been identified (5). It is known that MMP-7 has the highest activity among the MMPs (6). MMP-7 activates MMP-2 and MMP-9, and it plays a central role in the degradation of the ECM, including type IV collagen (7).

It has been reported that the stage of tumor progression in human gastric carcinoma is associated with the level of E-cadherin and MMP-7, respectively. However, there has been no report on metastasis and the E-cadherin and MMP-7 interrelationship for gastric carcinoma relating to the Wnt signaling pathway. In this study, we investigated the correlation between E-cadherin and MMP-7 in gastric carcinoma tissue and in the corresponding non-neoplastic 
Table I. Expression of ECD and MMP-7 in tumor tissue and non-neoplastic tissue from patients with gastric cancer ( $\mathrm{n}=42$ ).

\begin{tabular}{|c|c|c|c|c|c|c|}
\hline & \multicolumn{3}{|c|}{ Non-neoplastic tissue } & \multicolumn{3}{|c|}{ Tumor tissue } \\
\hline & \multicolumn{2}{|c|}{ Positive } & \multirow{2}{*}{$\begin{array}{c}\text { Ratio GAPDH } \\
\text { mean } \pm \text { SD }\end{array}$} & \multicolumn{2}{|c|}{ Positive } & \multirow{2}{*}{$\begin{array}{c}\text { Ratio GAPDH } \\
\text { mean } \pm \text { SD }\end{array}$} \\
\hline & $\mathrm{N}$ & $(\%)$ & & $\mathrm{N}$ & $(\%)$ & \\
\hline E-cadherin & 34 & 81.0 & $0.65 \pm 0.13$ & 21 & 50.0 & $0.55 \pm 0.17^{\mathrm{a}}$ \\
\hline MMP-7 & 21 & 50.0 & $0.57 \pm 0.19$ & 28 & 66.7 & $0.73 \pm 0.15^{\mathrm{b}}$ \\
\hline
\end{tabular}

${ }^{\mathrm{a}} \mathrm{p}<0.05 ;{ }^{\mathrm{b}} \mathrm{p}<0.01$ compared to non-neoplastic tissue.

mucosa. To identify whether E-cadherin and MMP-7 are prognostic factors, the association of these factors were studied with various clinicopathological features and the survival rates.

\section{Materials and methods}

Clinicopathological variables. Cancer specimens obtained from 42 patients with adenocarcinoma and the corresponding non-neoplastic mucosal tissues were investigated. There were 30 male and 12 female patients with a mean age of 60 years (age range: 29-75 years). The surgical-pathological tumor staging showed that two patients had stage I tumor, eight had stage II tumor, 14 had stage IIIa tumor, 3 had stage IIIb tumor and 15 had stage IV tumor. Thirty-two patients had regional or distant lymph node metastasis, and 10 patients showed no lymph node metastasis.

Reagent. The RT-PCR kits were purchased from Applied Biosystems (Foster city, CA, USA). The RNA-bee solution for total-RNA isolation was obtained from TEL-TEST (Friendswood, TX, USA). The 100-bp DNA ladder as a molecular weight marker was obtained from Takara (Kyoto, Japan). The 50-bp DNA ladder as a molecular weight marker was obtained from Invitrogen (Carlsbad, CA, USA). All the other reagents were commercial preparations of a pure grade.

Specimens and total-RNA isolation. We used the normal and tumor portions of stomach cancer specimens. Both specimens were freshly obtained from surgery and they were initially stored in a $\mathrm{N}_{2}$ tank until they were used for total-RNA isolation. The specimens from the $\mathrm{N}_{2}$ tank were ground into powder on dry ice with a hand grinder, and the total-RNA was then isolated with the use of RNA-bee solution as per the instructions by the manufacturer. Briefly, after the addition of $1 \mathrm{ml}$ of RNAbee and $200 \mu 1$ of chloroform and followed by centrifugation, the aqueous phase was combined with an equal volume of isopropanol. The precipitated pellet was washed with $70 \%$ ethanol and it was suspended again in diethylpyrocarbonate (DEPC)-treated water.

Reverse transcriptase-polymerase chain reaction (RT-PCR). Total-RNA ( $1 \mu \mathrm{g}$ per sample) was reverse transcribed using Moloney murine leukemia virus reverse transcriptase (Applied
Biosystems) and oligo dT priming according to the manufacturer's instruction, at $42^{\circ} \mathrm{C}$ for $15 \mathrm{~min}$. Amplification with specific primers was performed in a Gene Amp PCR system 9600 (Perkin-Elmer) for 25 cycles with a $15 \mathrm{sec} / 94^{\circ} \mathrm{C}$ denaturation step, a $15 \mathrm{sec} / 58^{\circ} \mathrm{C}$ annealing step and a $30 \mathrm{sec} / 72^{\circ} \mathrm{C}$ extension step in the case of E-cadherin (597 bp); for 40 cycles with a $40 \mathrm{sec} / 94^{\circ} \mathrm{C}$ denaturation step, a $55 \mathrm{sec} / 62^{\circ} \mathrm{C}$ annealing step and a $55 \mathrm{sec} / 72^{\circ} \mathrm{C}$ extension step in the case of E-cadherin (352 bp); for 33 cycles with a $20 \mathrm{sec} / 94^{\circ} \mathrm{C}$ denaturation step, a $30 \mathrm{sec} / 60^{\circ} \mathrm{C}$ annealing step and a $30 \mathrm{sec} / 72^{\circ} \mathrm{C}$ extension step in the case of MMP-7; for 30 cycles with a $30 \mathrm{sec} / 95^{\circ} \mathrm{C}$ denaturation step, a $30 \mathrm{sec} / 60^{\circ} \mathrm{C}$ annealing step and a $30 \mathrm{sec} /$ $72^{\circ} \mathrm{C}$ extension step in the case of GAPDH. Amplification of the mRNA for the housekeeping gene GAPDH was used as an internal quality standard. The amplified products were electrophoresed on $1.5-2 \%$ agarose gel and then they were stained with $0.5 \mu \mathrm{g} / \mathrm{ml}$ ethidium bromide. The primer sequences were as follows: GAPDH (178 bp) sense; 5'-acccactcctccacct ttg-3', antisense; 5'-ctcttgtgctcttgctggg-3', E-cadherin (352 bp) sense; 5'-gaggagagcggtggtcaaag-3', antisense; 5'-gttcagggagct cagactag-3', MMP-7 (103 bp) sense; 5'-ccccctgcatttcaggaa-3', antisense; 5'-tcctggcccatcaaatgg-3'.

Statistical analysis. All the statistical analyses were performed using SPSS for Windows (version 11.5). The independent two-tailed t-test was used to compare the E-cadherin and MMP-7 mRNA expressions. When appropriate, the data were presented as means \pm SD. Frequency tables and the $\chi^{2}$ test were used. Life-table probabilities for the overall survival were calculated by the method of Kaplan and Meier, and the differences in survival between the subgroups were compared with the log-rank test. The correlation between the ECD and MMP-7 mRNA/GAPDH ratio was analyzed by linear regression. To define the independent risk factors for the prognosis, multivariate analysis was performed with a Cox proportional hazards model. A p-value of $<0.05$ was considered as significant.

\section{Results}

Expression of E-cadherin and MMP-7. We used RT-PCR to detect the ECD and MMP-7 mRNA expressions. ECD and MMP-7 were expressed in the tumor tissue of 21/42 (50.0\%) and $28 / 42(66.7 \%)$ patients, respectively. In the corresponding 


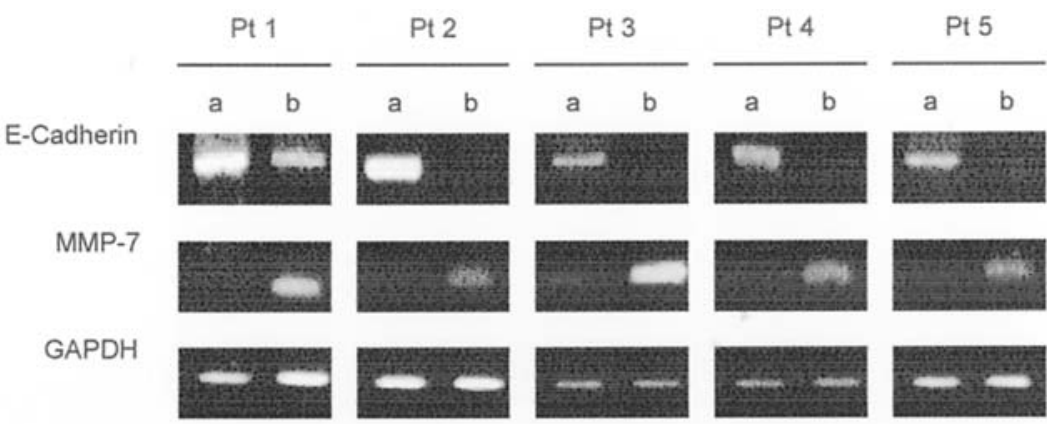

Figure 1. Strong expression of E-Cadherin and MMP-7 mRNA in tumor tissue compared with the non-neoplastic tissue in several samples of gastric cancer. Total-RNA was isolated from both normal (a) and tumor (b) tissues in gastric cancer.

Table II. Relationship between E-cadherin and MMP-7 mRNA expression in gastric cancer patients $(\mathrm{p}=0.512)$.

\begin{tabular}{|c|c|c|c|c|c|c|}
\hline & \multicolumn{6}{|c|}{ MMP-7 expression } \\
\hline & \multicolumn{2}{|c|}{ Negative } & \multicolumn{2}{|c|}{ Positive } & \multicolumn{2}{|c|}{ Total } \\
\hline & $\mathrm{N}$ & $(\%)$ & $\mathrm{N}$ & $(\%)$ & $\mathrm{N}$ & $(\%)$ \\
\hline \multicolumn{7}{|l|}{$\begin{array}{l}\text { ECD } \\
\text { expression }\end{array}$} \\
\hline Negative & 6 & 28.6 & 15 & 71.4 & 21 & 50 \\
\hline Positive & 8 & 38.1 & 13 & 61.9 & 21 & 50 \\
\hline Total & 14 & 33.3 & 28 & 66.7 & 42 & \\
\hline
\end{tabular}

non-neoplastic tissue, the expression of ECD and MMP-7 mRNA was found in $34 / 42(81.0 \%)$ and $21 / 42(50.0 \%)$ patients, respectively (Table I). When the levels of ECD and MMP-7 mRNA in each sample were normalized for the levels of GAPDH mRNA, the ECD mRNA levels were lower, but the MMP-7 mRNA levels were higher in the tumor tissue than in the corresponding non-neoplastic mucosal tissue (Fig. 1). The rate of positive ECD expression and negative MMP-7 expression and the rate of negative ECD expression and positive MMP-7 mRNA expression were 38.1 and $71.4 \%$, respectively ( $\mathrm{p}=0.51$; Table II). However, there was no negative correlation between the expression levels of ECD and MMP-7 on the linear regression analysis ( $\mathrm{r}=0.158, \mathrm{p}=0.319$ ) (Fig. 2).

Relationship between the ECD and MMP-7 expressions and the clinicopathological features. To evaluate the interactions between the expression of ECD and MMP-7 mRNA and their effect on the patient prognosis, we checked the relationship between the expression of the two genes and the established prognostic factors. The ECD mRNA expression was significantly correlated with the Ming classification $(\mathrm{p}=0.01)$, lymph node metastases $(\mathrm{p}=0.04)$, and their stages $(\mathrm{p}=0.04)$ (Table III). The overexpression of MMP-7 mRNA was significantly correlated to the Lauren classification $(\mathrm{p}=0.04)$, the Ming classification $(\mathrm{p}=0.02)$, lymph node metastases $(\mathrm{p}=0.02)$, and the tumor stages $(\mathrm{p}=0.01)$ (Table IV) of gastric carcinoma. Other variables such as tumor size, the macroscopic type, lymphatic

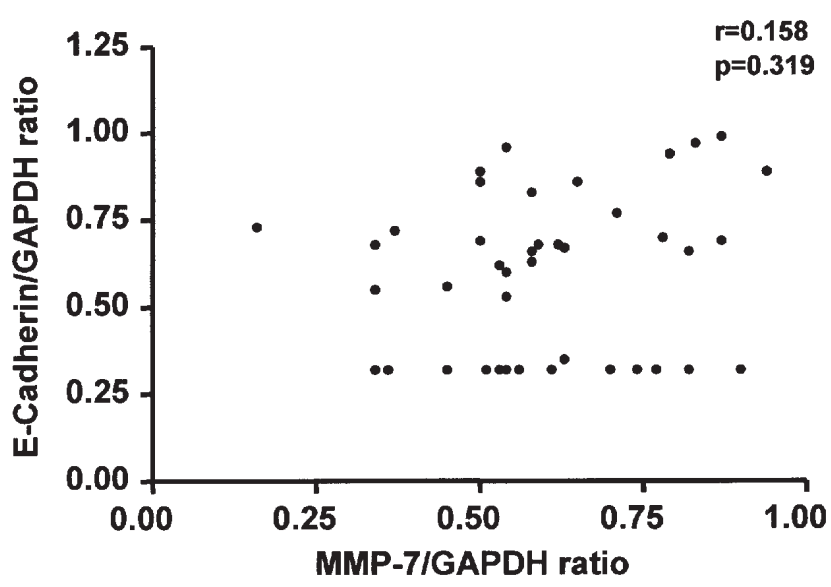

Figure 2. Correlation between the expression levels of E-cadherin and MMP-7 mRNA in gastric cancer tissue.

vessel invasion and neural invasion did not demonstrate any correlation.

The ECD and MMP-7 mRNA expressions and the survival rates. The overall survival rate of the 42 patients with gastric carcinoma was stratified according to the ECD and MMP-7 mRNA expressions, and the results are shown in Figs. 3 and 4. The patients with the negative expression of E-cadherin mRNA in the gastric carcinoma tissue had a shorter survival (median: 22.1 months; 95\% CI 11.9-32.3 months) than did the patients in whom the expression of E-cadherin mRNA was positive (median: 34.0 months; 95\% CI 30.0-38.0 months, $\mathrm{p}=0.216$ ). The Kaplan-Meier curves showed that there was no significant correlation between the ECD mRNA expression and the overall survival. On the other hand, patients with a positive expression of MMP-7 mRNA in their gastric carcinoma tissue had a shorter survival (median: 24.1 months; 95\% CI 20.1-28.3 months) than did the patients who had gastric carcinoma tissue with a MMP-7 mRNA expression (median: 48.8 months, $\mathrm{p}=0.003)$. In multivariate analysis, the overexpresssion of MMP-7 ( $\mathrm{p}=0.01)$ emerged as an independent prognostic factor from eight variables (age, Lauren classification, Ming classification, lymph node metastasis, vascular invasion, stage, ECD mRNA expression and MMP-7 mRNA expression), but the abnormal expression of E-cadherin failed to provide independent prognostic value $(\mathrm{p}=0.174)$. 
Table III. Relationship between E-cadherin expression and clinicopathological features in patients with gastric cancer.

\begin{tabular}{|c|c|c|c|c|c|c|}
\hline \multirow{3}{*}{$\begin{array}{l}\text { Clinicopathological } \\
\text { features }\end{array}$} & \multirow[b]{3}{*}{$\mathrm{N}$} & \multicolumn{4}{|c|}{ Expression of E-cadherin } & \multirow[b]{3}{*}{ P-value } \\
\hline & & \multicolumn{2}{|c|}{ Negative } & \multicolumn{2}{|c|}{ Positive } & \\
\hline & & $\mathrm{N}$ & $(\%)$ & $\mathrm{N}$ & $(\%)$ & \\
\hline Tumor size & & & & & & 0.158 \\
\hline$\leq 5 \mathrm{~cm}$ & 4 & 2 & 50 & 2 & 50 & \\
\hline$>5 \mathrm{~cm}$ & 38 & 6 & 15.8 & 32 & 84.2 & \\
\hline Histologic type & & & & & & 0.756 \\
\hline Differentiated & 18 & 8 & 44.4 & 10 & 55.6 & \\
\hline Undifferentiated & 24 & 13 & 54.2 & 11 & 45.8 & \\
\hline Macroscopic type & & & & & & 1.000 \\
\hline Bormann 1,2 & 18 & 9 & 50 & 9 & 50 & \\
\hline Bormann 3,4 & 24 & 12 & 50 & 12 & 50 & \\
\hline Lauren classification & & & & & & 0.112 \\
\hline Intestinal & 15 & 9 & 60 & 6 & 40 & \\
\hline Diffuse & 20 & 11 & 55 & 9 & 45 & \\
\hline Mixed & 7 & 1 & 14.3 & 6 & 85.7 & \\
\hline Ming classification & & & & & & 0.010 \\
\hline Expanding & 4 & 2 & 50 & 2 & 50 & \\
\hline Infiltrative & 30 & 18 & 60 & 12 & 40 & \\
\hline Mixed & 8 & 0 & 0 & 8 & 100 & \\
\hline Serosal invasion & & & & & & 1.000 \\
\hline Negative & 15 & 7 & 46.7 & 8 & 53.3 & \\
\hline Positive & 27 & 14 & 51.9 & 13 & 48.1 & \\
\hline Lymph node metastases & & & & & & 0.047 \\
\hline Negative & 10 & 2 & 20 & 8 & 80 & \\
\hline Positive & 32 & 18 & 56.3 & 14 & 43.8 & \\
\hline Vascular invasion & & & & & & 0.758 \\
\hline Negative & 20 & 11 & 55 & 9 & 45 & \\
\hline Positive & 22 & 10 & 45.5 & 12 & 54.5 & \\
\hline Lymphatic vessel invasion & & & & & & 1.000 \\
\hline Negative & 24 & 12 & 50 & 12 & 50 & \\
\hline Positive & 18 & 9 & 50 & 9 & 50 & \\
\hline Neural invasion & & & & & & 1.000 \\
\hline Negative & 16 & 8 & 50 & 8 & 50 & \\
\hline Positive & 26 & 13 & 50 & 13 & 50 & \\
\hline Omental invasion & & & & & & 0.750 \\
\hline Negative & 20 & 9 & 45 & 11 & 55 & \\
\hline Positive & 22 & 12 & 54.5 & 10 & 45.5 & \\
\hline Stage & & & & & & 0.048 \\
\hline Stage I & 2 & 0 & 0 & 2 & 100 & \\
\hline Stage II & 8 & 2 & 25 & 6 & 75 & \\
\hline Stage IIIa & 14 & 9 & 64.3 & 5 & 35.7 & \\
\hline Stage IIIb & 3 & 3 & 100 & 0 & 0 & \\
\hline Stage IV & 15 & 5 & 33.3 & 10 & 66.7 & \\
\hline
\end{tabular}


Table IV. Relationship between MMP-7 expression and clinicopathological features in patients with gastric cancer.

\begin{tabular}{|c|c|c|c|c|c|c|}
\hline \multirow{3}{*}{$\begin{array}{l}\text { Clinicopathological } \\
\text { features }\end{array}$} & \multirow[b]{3}{*}{$\mathrm{N}$} & \multicolumn{4}{|c|}{ Expression of MMP-7 } & \multirow[b]{3}{*}{ P-value } \\
\hline & & \multicolumn{2}{|c|}{ Negative } & \multicolumn{2}{|c|}{ Positive } & \\
\hline & & $\mathrm{N}$ & $(\%)$ & $\mathrm{N}$ & $(\%)$ & \\
\hline Tumor size & & & & & & 0.590 \\
\hline$\leq 5 \mathrm{~cm}$ & 4 & 2 & 50 & 2 & 50 & \\
\hline$>5 \mathrm{~cm}$ & 38 & 12 & 31.6 & 26 & 68.4 & \\
\hline Histologic type & & & & & & 0.742 \\
\hline Differentiated & 18 & 5 & 27.8 & 13 & 72.2 & \\
\hline Undifferentiated & 24 & 9 & 37.5 & 15 & 62.5 & \\
\hline Macroscopic type & & & & & & 0.742 \\
\hline Bormann 1,2 & 18 & 5 & 27.8 & 13 & 72.2 & \\
\hline Bormann 3,4 & 24 & 9 & 37.5 & 15 & 62.5 & \\
\hline Lauren classification & & & & & & 0.043 \\
\hline Intestinal & 15 & 11 & 73.3 & 4 & 26.7 & \\
\hline Diffuse & 20 & 7 & 35 & 13 & 65 & \\
\hline Mixed & 7 & 2 & 28.6 & 5 & 71.4 & \\
\hline Ming classification & & & & & & 0.027 \\
\hline Expanding & 4 & 3 & 75 & 1 & 25 & \\
\hline Infiltrative & 30 & 7 & 23.3 & 23 & 76.7 & \\
\hline Mixed & 8 & 5 & 62.5 & 3 & 37.5 & \\
\hline Serosal invasion & & & & & & 0.637 \\
\hline Negative & 15 & 5 & 33.3 & 10 & 66.7 & \\
\hline Positive & 27 & 9 & 33.3 & 18 & 66.7 & \\
\hline Lymph node metastases & & & & & & 0.027 \\
\hline Negative & 10 & 7 & 70 & 3 & 30 & \\
\hline Positive & 32 & 8 & 25 & 24 & 75 & \\
\hline Vascular invasion & & & & & & 0.75 \\
\hline Negative & 20 & 6 & 30 & 14 & 70 & \\
\hline Positive & 22 & 8 & 36.4 & 14 & 63.6 & \\
\hline Lymphatic vessel invasion & & & & & & 1.000 \\
\hline Negative & 24 & 8 & 33.3 & 16 & 66.7 & \\
\hline Positive & 18 & 6 & 33.3 & 12 & 66.7 & \\
\hline Neural invasion & & & & & & 0.431 \\
\hline Negative & 16 & 7 & 49.8 & 9 & 56.3 & \\
\hline Positive & 26 & 7 & 26.9 & 19 & 73.1 & \\
\hline Omental invasion & & & & & & 1.000 \\
\hline Negative & 20 & 7 & 35 & 13 & 65 & \\
\hline Positive & 22 & 7 & 31.8 & 15 & 68.2 & \\
\hline Stage & & & & & & 0.008 \\
\hline Stage I & 2 & 2 & 100 & 0 & 0 & \\
\hline Stage II & 8 & 6 & 75 & 2 & 25 & \\
\hline Stage IIIa & 14 & 2 & 14.3 & 12 & 85.7 & \\
\hline Stage IIIb & 3 & 1 & 33.3 & 2 & 66.7 & \\
\hline Stage IV & 15 & 3 & 20 & 12 & 80 & \\
\hline
\end{tabular}




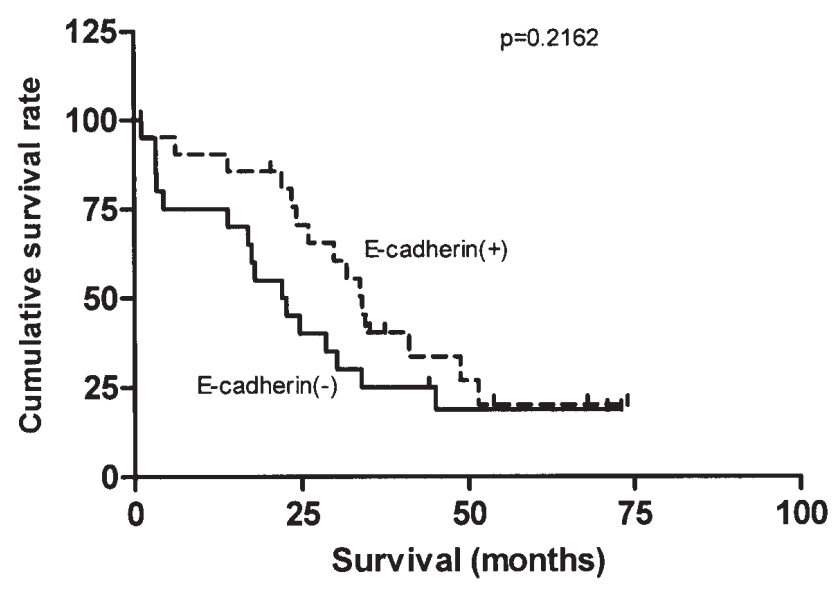

Figure 3. Kaplan-Meier survival curve for patients with gastric cancer: Ecadherin positive vs. E-cadherin negative. The difference in the median survival between the patients with tumor displaying E-cadherin and the patients without E-cadherin is not statistically significant.

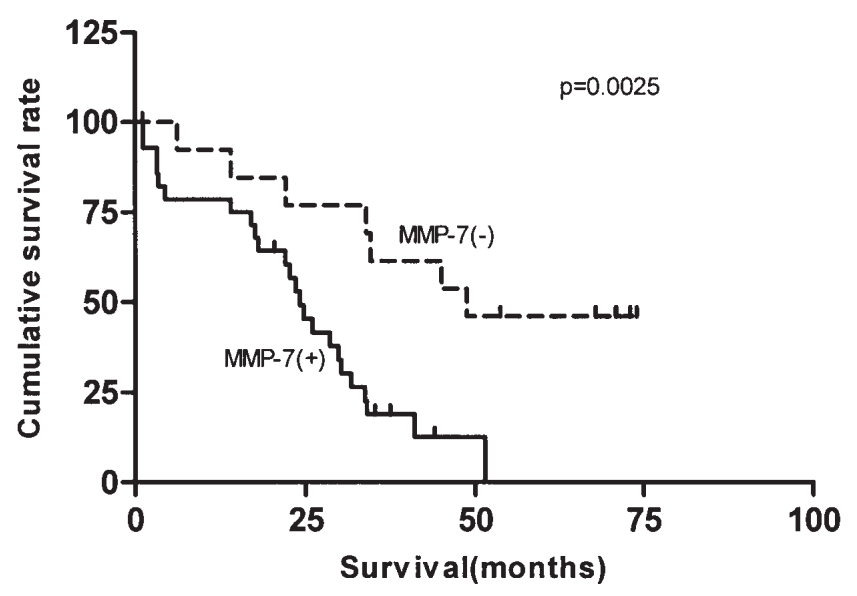

Figure 4. Kaplan-Meier survival curve for patients with gastric cancer: MMP-7 positive vs. MMP-7 negative. The survival rate of patients with a tumor expressing MMP-7 was significantly lower than that of patients without MMP-7.

\section{Discussion}

Patients with metastasis show a poor prognosis, whereas those without metastasis tend to show a favorable prognosis (8). Thus, to improve the clinical outcome of patients with gastric carcinoma, it is important to clarify the biological mechanisms of tumor progression and metastases (9). The loss of cellular cohesion is a characteristic of malignant cells, and it leads to cell-matrix detachment, invasion and migration (10). As a family of transmembrane glycoproteins, the adherins mediate cell adhesion and they have an important role in morphogenesis and for maintaining the differentiated phenotype (10). E-cadherin is the predominant cadherin family member that is expressed in epithelial tissue. A decline of Ecadherin function in tumors results in the rapid progression of tumor, not only for metastatic carcinoma, but also for the relatively benign adenoma. Cells that have germline mutation in E-cadherin have a predisposition to diffuse and to be poorly differentiated, and E-cadherin down-regulation in sporadic tumors is associated with a poor clinical prognosis (11).
Consistent loss of E-cadherin expression has been reported in lobular breast cancer (12-15) and carcinoma of the prostate (16-18), stomach (19), bladder $(20-22)$, colorectum $(23,24)$ and pancreas (25). It has been correlated with a reduced survival and poor prognosis in patients with cancer $(26,27)$. Dai et al (28) found that the positive rates of the E-cadherin and $\alpha$ catenin expressions were 38.6 and $28.6 \%$, respectively, and they were significantly reduced in the gastric carcinoma that had a more prominent malignant phenotype, such as stage III/IV tumor with poor cell differentiation, poor TNM staging and prognosis, invasion through the serosa and lymph nodes, and liver metastases. Joo et al (29) reported that the immunoreactivity of E-cadherin and $\alpha, \beta$ and $\gamma$-catenin was expressed by normal gastric epithelial cells with strong membranous staining at the intercellular border, and a reduced expression of them occurred in a considerable proportion of both the early and advanced cancer groups; this was correlated with the diffuse type of cancer that had poor differentiation, but it was not related with the depth of invasion or lymph node metastases. In the present study, we found that the positive expression of E-cadherin mRNA was detected in 34 of 42 cases of normal gastric mucosal tissue, but only in 21 gastric carcinoma tissues. The abnormal expression of this mRNA was significantly correlated with the Ming classification, lymph node metastases and the tumor stage.

In addition to cleaving ECM proteins, MMPs play an important role in mediating the shedding of transmembrane and membrane-associated proteins, including E-cadherin. As dissociation of $\beta$-catenin from the cadherin-catenin complex in the membrane is a prerequisite for $\beta$-catenin-mediated signaling, cleavage of the cadherins by the MMPs may play a critical role in regulating this signaling pathway (30). MMP-7 mRNA and protein are expressed not only in the epithelium of premalignant lesions in many glandular tissues (31) but they are also expressed in the tumor cells, and this is associated with the tumor progression of colorectal (32), gastric (33) and hepatic carcinoma (34). It has been reported that MMP-7 proteins are expressed at the invasive front of human colon cancer (35), and the level of expression is correlated with the stage of tumor progression $(36,37)$. Overexpression of MMP-7 in esophageal cancer and human pancreatic cancer was reported to correlate with a poor prognosis (38-41). Liu et al (42) have reported that a high frequency of MMP-7 protein at the invasive front in gastric carcinoma was related to a poor prognosis. There are also several reports that peritoneal dissemination and lymph node metastasis are associated with MMP-7 in gastric carcinoma (43-48). In this study, we found that the positive expression of MMP-7 mRNA was observed in 21 of the 42 cases of normal gastric mucosal tissues, but this was seen in only 28 gastric carcinoma tissues. The overexpression of MMP-7 mRNA significantly correlated with the Lauren and Ming classifications, lymph node metastases, tumor stage and the survival rate.

On the multiple logistic regression analysis, the overexpression of MMP-7 mRNA was identified as an independent predictor of metastasis.

The interaction between E-cadherin and $\beta$-catenin at the adherens junction provides an obvious mechanism by which the mutation of CDH1 could disrupt growth signaling thus initiating tumorigenesis. In addition to its role in regulating 
cell adhesion, ß-catenin is a transcription co-factor in the Wnt signaling pathway, and elevated levels of free $\beta$-catenin are associated with tumorigenesis in humans. The loss of functional E-cadherin would be expected to shift the cellular equilibrium of $B$-catenin away from the adherens junction towards the pool of free- $\beta$-catenin (11). Increased free $B$-catenin would activate the transcriptional targets of the Wnt singnalling pathway, and these include c-myc, cyclin D1, c-jun, Tcf-1, PPAR and MMP-7 (3). The abnormal expression of E-cadherin will increase the expression of MMP-7 mRNA. However, our results showed that there was no correlation between the expression levels of ECD and MMP-7 on the linear regression analysis. Therefore, further studies should aim at identifying the expression level of the E-cadherin, B-catenin and MMP-7 mRNA and the related proteins. In addition, it is important to obtain high-quality RNA from samples and to select specific cell populations so as to avoid averaging out the heterogeneous elements of a sample.

In conclusion, there were no correlations between the expression of E-cadherin and MMP-7. These data indicate that the overexpression of MMP-7 may be considered as a useful marker for determining metastasis and the prognosis of human gastric carcinoma.

\section{Acknowledgements}

This work was supported by a grant from the MOST/KOSEF to the National Core Research Center for Systems Bio-Dynamics (R15-2004-033).

\section{References}

1. Fidler IJ: Molecular pathology of gastroenterological cancer. Springer-Verlag, Berlin, 1997.

2. Meyer T and Hart IR: Mechanisms of tumour metastasis. Eur J Cancer 34: 214-221, 1998.

3. Li YJ, Wei ZM, Meng YX and Ji XR: Beta-catenin up-regulates the expression of cyclinD1, c-myc and MMP-7 in human pancreatic cancer: relationships with carcinogenesis and metastasis. World J Gastroenterol 11: 2117-2123, 2005.

4. Denys H, De Wever O, Nusgens B, et al: Invasion and MMP expression profile in desmoid tumours. Br J Cancer 90: 1443-1449, 2004.

5. Egeblad M and Werb Z: New functions for the matrix metalloproteinases in cancer progression. Nat Rev Cancer 2: 161-174, 2002.

6. Imai K, Yokohama Y, Nakanishi I, Ohuchi E, Fujii Y and Nakai N: Matrix metalloproteinase 7 (matrilysin) from human rectal carcinoma cells. Activation of the precursor, interaction with other matrix metalloproteinases and enzyme properties. J Biol Chem 270: 6691-6697, 1995.

7. Parsons SL, Watson SA, Brown PD, Collins HM and Steele RJ: Matrix metalloproteinases. Br J Surg 84: 160-166, 1997.

8. Mori M, Mimori K, Shiraishi T, Tanaka S, Ueo H, Sugimachi K and Akiyoshi T: p27 expression and gastric carcinoma. Nat Med 3: 593, 1997.

9. Mori M, Mimori K, Yoshikawa Y, et al: Analysis of the geneexpression profile regarding the progression of human gastric carcinoma. Surgery 131: S39-S47, 2002.

10. Choong PF: The molecular basis of skeletal metastases. Clin Orthop Relat Res 415 (Suppl): S19-S31, 2003.

11. Guilford P: E-cadherin down-regulation in cancer: fuel on the fire? Mol Med Today 5: 172-177, 1999.

12. Siitonen SM, Kononen JT, Helin HJ, Rantala IS, Holli KA and Isola JJ: Reduced E-cadherin expression is associated with invasiveness and unfavorable prognosis in breast cancer. Am J Clin Pathol 105: 394-402, 1996.

13. Palacios J, Benito N, Pizarro A, Suarez A, Espada J, Cano A and Gamallo C: Anomalous expression of P-cadherin in breast carcinoma. Correlation with E-cadherin expression and pathological features. Am J Pathol 146: 605-612, 1995.
14. Gupta SK, Douglas-Jones AG, Jasani B, Morgan JM, Pignatelli M and Mansel RE: E-cadherin (E-cad) expression in duct carcinoma in situ (DCIS) of the breast. Virchows Arch 430: 23-28, 1997.

15. Gamallo C, Palacios J, Suarez A, Pizarro A, Navarro P, Quintanilla M and Cano A: Correlation of E-cadherin expression with differentiation grade and histological type in breast carcinoma. Am J Pathol 142: 987-993, 1993.

16. Umbas R, Schalken JA, Aalders TW, et al: Expression of the cellular adhesion molecule E-cadherin is reduced or absent in high-grade prostate cancer. Cancer Res 52: 5104-5109, 1992.

17. Umbas R, Isaacs WB, Bringuier PP, et al: Decreased E-cadherin expression is associated with poor prognosis in patients with prostate cancer. Cancer Res 54: 3929-3933, 1994.

18. Cheng L, Nagabhushan M, Pretlow TP, Amini SB and Pretlow TG: Expression of E-cadherin in primary and metastatic prostate cancer. Am J Pathol 148: 1375-1380, 1996.

19. Matsui S, Shiozaki H, Inoue M, et al: Immunohistochemical evaluation of alpha-catenin expression in human gastric cancer. Virchows Arch 424: 375-381, 1994.

20. Syrigos KN, Krausz T, Waxman J, Pandha H, RowlinsonBusza G, Verne J, Epenetos AA and Pignatelli M: E-cadherin expression in bladder cancer using formalin-fixed, paraffinembedded tissues: correlation with histopathological grade, tumour stage and survival. Int J Cancer 64: 367-370, 1995.

21. Shimazui T, Schalken JA, Giroldi LA, Jansen CF, Akaza H, Koiso K, Debruyne FM and Bringuier PP: Prognostic value of cadherin-associated molecules (alpha-, beta- and gamma-catenins and p120cas) in bladder tumors. Cancer Res 56: 4154-4158, 1996.

22. Bringuier PP, Umbas R, Schaafsma HE, Karthaus HF, Debruyne FM and Schalken JA: Decreased E-cadherin immunoreactivity correlates with poor survival in patients with bladder tumors. Cancer Res 53: 3241-3245, 1993.

23. Dorudi S, Sheffield JP, Poulsom R, Northover JM and Hart IR: E-cadherin expression in colorectal cancer. An immunocytochemical and in situ hybridization study. Am J Pathol 142: 981-986, 1993.

24. Dorudi S, Hanby AM, Poulsom R, Northover J and Hart IR: Level of expression of E-cadherin mRNA in colorectal cancer correlates with clinical outcome. Br J Cancer 71: 614-616, 1995.

25. Pignatelli M, Ansari TW, Gunter P, Liu D, Hirano S, Takeichi M, Kloppel $\mathrm{G}$ and Lemoine NR: Loss of membranous E-cadherin expression in pancreatic cancer: correlation with lymph node metastasis, high grade, and advanced stage. J Pathol 174: 243-248, 1994.

26. Nakanishi Y, Ochiai A, Akimoto S, Kato H, Watanabe H, Tachimori Y, Yamamoto S and Hirohashi S: Expression of Ecadherin, alpha-catenin, beta-catenin and plakoglobin in esophageal carcinomas and its prognostic significance: immunohistochemical analysis of 96 lesions. Oncology 54: 158-165, 1997.

27. Birchmeier $\mathrm{W}$ and Behrens J: Cadherin expression in carcinomas: role in the formation of cell junctions and the prevention of invasiveness. Biochim Biophys Acta 1198: 11-26, 1994.

28. Dai D, Chen J and $\mathrm{Xu} \mathrm{H}$ : The clinical significance of Ecadherin and alpha-catenin expression in human gastric cancer. Chung-Hua chung Liu Tsa Chih 23: 35-38, 2001.

29. Joo YE, Rew JS, Kim HS, Choi SH, Park CS and Kim SJ: Changes in the E-cadherin-catenin complex expression in early and advanced gastric cancers. Digestion 64: 111-119, 2001.

30. Mei JM, Borchert GL, Donald SP and Phang JM: Matrix metalloproteinase(s) mediate(s) NO-induced dissociation of beta-catenin from membrane bound E-cadherin and formation of nuclear beta-catenin/LEF-1 complex. Carcinogenesis 23: 2119-2122, 2002.

31. Powell WC and Matrisian LM: Complex roles of matrix metalloproteinases in tumor progression. Curr Top Microbiol Immunol 213: 1-21, 1996.

32. Leeman MF, Curran S and Murray GI: New insights into the roles of matrix metalloproteinases in colorectal cancer development and progression. J Pathol 201: 528-534, 2003.

33. Huachuan Z, Xiaohan L, Jinmin S, Qian C, Yan X and Yinchang Z: Expression of matrix metalloproteinase-7 involving in growth, invasion, metastasis and angiogenesis of gastric cancer. Chin Med Sci J 18: 80-86, 2003.

34. Yamamoto H, Itoh F, Adachi Y, Fukushima H, Itoh H, Sasaki S, Hinoda $\mathrm{Y}$ and Imai $\mathrm{K}$ : Messenger RNA expression of matrix metalloproteinases and tissue inhibitors of metalloproteinases in human hepatocellular carcinoma. Jpn J Clin Oncol 29: 58-62, 1996. 
35. Adachi Y, Yamamoto H, Itoh F, Hinoda Y, Okada Y and Imai K: Contribution of matrilysin (MMP-7) to the metastatic pathway of human colorectal cancers. Gut 45: 252-258, 1999.

36. Ougolkov AV, Yamashita K, Mai M and Minamoto T: Oncogenic beta-catenin and MMP-7 (matrilysin) cosegregate in late-stage clinical colon cancer. Gastroenterology 122: 60-71, 2002.

37. Mori M, Barnard GF, Mimori K, Ueo H, Akiyoshi T and Sugimachi K: Overexpression of matrix metalloproteinase-7 mRNA in human colon carcinomas. Cancer 75: 1516-1519, 1995.

38. Adachi Y, Yamamoto H, Itoh F, Arimura Y, Nishi M, Endo T and Imai $\mathrm{K}$ : Clinicopathologic and prognostic significance of matrilysin expression at the invasive front in human colorectal cancers. Int J Cancer 95: 290-294, 2001.

39. Yamamoto H, Adachi Y, Itoh F, Iku S, Matsuno K, Kusano M, Arimura Y, Endo T, Hinoda Y, Hosokawa M and Imai K: Association of matrilysin expression with recurrence and poor prognosis in human esophageal squamous cell carcinoma. Cancer Res 59: 3313-3316, 1999.

40. Yamamoto H, Itoh F, Iku S, Adachi Y, Fukushima H, Sasaki S, Mukaiya M, Hirata K and Imai K: Expression of matrix metalloproteinases and tissue inhibitors of metalloproteinases in human pancreatic adenocarcinomas: clinicopathologic and prognostic significance of matrilysin expression. J Clin Oncol 19: 1118-1127, 2001.

41. Yamashita K, Mori M, Shiraishi T, Shibuta K and Sugimachi K: Clinical significance of matrix metalloproteinase-7 expression in esophageal carcinoma. Clin Cancer Res 6: 1169-1174, 2000.

42. Liu XP, Kawauchi S, Oga A, Tsushimi K, Tsushimi M, Furuya T and Sasaki K: Prognostic significance of matrix metalloproteinase-7 (MMP-7) expression at the invasive front in gastric carcinoma. Jpn J Cancer Res 93: 291-295, 2002.
43. Adachi Y, Itoh F, Yamamoto H, Matsuno K, Arimura Y, Kusano M, Endoh T, Hinoda Y, Oohara M, Hosokawa M and Imai K: Matrix metalloproteinase matrilysin (MMP-7) participates in the progression of human gastric and esophageal cancers. Int J Oncol 13: 1031-1035, 1998 .

44. Honda M, Mori M, Ueo H, Sugimachi K and Akiyoshi T: Matrix metalloproteinase-7 expression in gastric carcinoma. Gut 39: 444-448, 1996.

45. Nagashima Y, Hasegawa S, Koshikawa N, Taki A, Ichikawa Y, Kitamura H, Misugi K, Kihira Y, Matuo Y, Yasumitsu H and Miyazaki K: Expression of matrilysin in vascular endothelial cells adjacent to matrilysin-producing tumors. Int J Cancer 72: 441-445, 1997.

46. Senota A, Itoh F, Yamamoto H, Adachi Y, Hinoda Y and Imai K: Relation of matrilysin messenger RNA expression with invasive activity in human gastric cancer. Clin Exp Metastasis 16: 313-321, 1998.

47. Yonemura Y, Endou Y, Fujita H, Fushida S, Bandou E, Taniguchi K, Miwa K, Sugiyama K and Sasaki T: Role of MMP-7 in the formation of peritoneal dissemination in gastric cancer. Gastric Cancer 3: 63-70, 2000.

48. Yonemura Y, Fujimura T, Ninomiya I, Kim BS, Bandou E, Sawa T, Kinoshita K, Endo Y, Sugiyama K and Sasaki T: Prediction of peritoneal micrometastasis by peritoneal lavaged cytology and reverse transcriptase-polymerase chain reaction for matrix metalloproteinase-7 mRNA. Clin Cancer Res 7: 1647-1653, 2001. 